Canadian University Music Review

Revue de musique des universités canadiennes

\title{
The Sociology of Music
}

\section{Jan Ling}

Numéro 5, 1984

URI : https://id.erudit.org/iderudit/1013928ar

DOI : https://doi.org/10.7202/1013928ar

Aller au sommaire du numéro

Éditeur(s)

Canadian University Music Society / Société de musique des universités

canadiennes

ISSN

0710-0353 (imprimé)

2291-2436 (numérique)

Découvrir la revue

Citer cet article

Ling, J. (1984). The Sociology of Music. Canadian University Music Review /

Revue de musique des universités canadiennes, (5), 1-16.

https://doi.org/10.7202/1013928ar

All Rights Reserved (C Canadian University Music Society / Société de musique des universités canadiennes, 1984
Ce document est protégé par la loi sur le droit d'auteur. L’utilisation des services d'Érudit (y compris la reproduction) est assujettie à sa politique d'utilisation que vous pouvez consulter en ligne.

https://apropos.erudit.org/fr/usagers/politique-dutilisation/ 


\section{THE SOCIOLOGY OF MUSIC*}

Jan Ling

In Sweden, over a relatively short but intensive period of time, the sociology of music has travelled the entire spectrum, moving from dry, computerized statistical studies to extremely personal "sensitivity" studies. There is no comprehensive academic research field known as sociology of music in Sweden, so the question that arises is whether people working in this area have any generalizable common objectives. In Sweden, I think sociologists of music would probably be willing to sign a statement formulated as follows: "Our primary aim is to attain a culture in which music is an active, integrated part of society and in which there is understanding for many different forms of musical expression. We also aim to develop new forms through which people can make use of well-functioning established ones."

In recent years the questions that have increasingly preoccupied sociologists of music have been: "What does music communicate?" and "What effects does music produce upon the listener?" These questions bring the work of the music sociologist close to that of the psychologist of music and other behavioral scientists.

Music is an excellent object of research for cultural sociologists precisely because it is a carrier of meaning without being descriptive. All that has to be done is to decode the meaning conveyed by the musical message! This is one of the fundamental tasks of the sociologist of music.

Music is often approached by the sociologist via its func-

*This article is a translation of "Musikens sociologi," in Hannerz, U., Liljeström, R., and Löfgren, O., eds., "Kultur och medventande," en tvärvetenskaplig analys. Stockholm: Akademilitteratur AB, 1982, 123-35. Reprinted by permission. 
tions. I will begin by exemplifying some of the broadest functions of music with the aid of some examples from music history.

\section{A Historical Perspective}

In The Divine Comedy, Dante Alighieri moves the reader, via the hand of Virgil, from the noises of Inferno, via the sounds of Purgatory with its light songs and music of earthly devotion, to the zenith of Paradise, where angels make heavenly music without end. Noise, sound, and music are the three levels that exist in all known societies. There are researchers who would see a further division of music into at least two levels: an original one of "body" music, and a secondary one which is more "intellectual and abstract." The latter level is then seen as having developed alongside the development of musical notation, the written language.

The emotional and intellectual development which moves from noise and sound to "music" is, unquestionably, a special ability peculiar to the human brain which, in completing this development, creates a philosophy of sound based on emotion, but of course in interplay with thought and language.

But the distinction between the components of this process that are "body" and those that are "intellectual and abstract" can never be made with accuracy and will always remain in the realm of speculation. What can be said is that the phenomenon of music has occurred through artistic use of our sound environment, or through communicative sounds, such as the sounds of language, being given an organized harmonic dimension. This has taken place in every known period of history, but in widely varying ways, depending upon what accumulation there has been of the "music" of the preceding period(s).

Although we appear to be quite capable of characterizing the music of exotic cultures and of the past, it is more difficult for us to describe music and musical functions that are contemporary and near at hand. This is the primary task of the music sociologist. I will attempt to specify the role of the phenomenon of music as a cultural indicator by using the following pair of concepts: culture and anti-culture.

Advanced ancient civilizations such as those of the Sumerians, Babylonians, and Egyptians had an official music culture, in which instruments, melodies, and the like had been inherited from immemorial nomadic and agricultural cultures. Through time, they had been transformed into cult instruments 
and cult songs. The gods, like the planets, the seasons, the dimensions of the temple, were classified in terms of simple numerical proportions such as 1:1, 1:2, 2:3, 3:4, which, in turn, when applied to segmenting the string, gave the consonant, concordant intervals-unison, octave, fifth, and fourth. The entire culture was permeated with a symbolic universe of sound, the musical norms of which were law, and where crimes in the form of untuned instruments or incorrect tube length were punished. When, for example, Nebuchadnezzar had the three men shut up in the burning oven it was not only because they refused to worship his image, but also because they refused to listen to the official music!

In a class-stratified society, more sophisticated entertainment-type music often develops in the middle class. This development is always similar when the philosophy and system of norms of a society are collapsing: extra-musical dogma is questioned, the ear becomes monumental in directing the development of vocal and instrumental splendor.

Every nation has established norms for the introduction of certain music, passed along via education, subsidized through financial support, and provided with an ethical or aesthetic "aura." Its objectives are generally preservative, conservative, that is, they fall into the category of "law and order." We can distinguish this most easily in a Herodotus-perspective, in the light of history, while its contours are more difficult to distinguish in contemporary research. This type of music is often on a par with the intellectual superstructure of the society, and is "interpreted" in accordance with it. This means, for example, that in a fascist State such as Germany was in the 1930s, Beethoven was "interpreted" in terms of motivation relating to the biology of the species as the sanctioned form of national music, while in socialist countries Beethoven is sanctioned in terms of his appeal to democracy, humanism, and freedom! How, then, can an adequate general definition be established for musical anti-cultures? They, too, have a number of aesthetic, national, and political attributes. As stated above they were a middle-class phenomenon until the mid-nineteenth century. Later they developed a more proletarian basis, which explains, among other things, the popularity of Afro-American music in European society. This anti-culture is seldom of a revolutionary nature; rather it is a complement to the established musical culture and is gradually assimilated into it. 
Let us take an example from seventeenth-century Europe. We can study the prevailing philosophy of music in Johannes Kepler's Harmonicis mundi libri (1619). According to Kepler, music was still considered a reflection of the harmony of the spheres, but rather than being so in terms of simple arithmetical proportions, it was now according to sophisticated geometric calculations, polygons and circles, in which a larger number of intervals could be mathematically "interpreted" as being correct. This geometrical conception of music was further combined with current numerical speculations in theology. The basis of the intellectual system was still Quintillian rhetoric. The poles of the official "ideologically determined music life" were thus:

1) Sacred music - written in accordance with the rules of theology, rhetoric, and mathematics.

2) Courtly music - written in accordance with the rhetoric of government and the rules of poetics.

The forms between these poles were represented by:

1) Middle-class music - written primarily in accordance with the two systems of rules mentioned above but with elements influenced by dance music.

2) Peasant-class music - characterized by "sorsatio," disorder, in which dance and folk music merge with working music in harmony, style, and means of expression.

During the eighteenth century, courtly and sacred music lost ground, and the ideological mortar holding the musical community together was associated with an incipient public, middle-class musical life which included public concerts, a middle-class opera-initially in addition to feudal opera-a growing market for music performances, and so on. Peasant folk music lived on in isolation or was transformed into entertainment music, as the sale of music avalanched into a wider and wider market. During the nineteenth century, middle-class music, in turn, was successively wrenched free from its ideology and gradually made increasingly aesthetically pleasing, while light music took over the role of ideological mortar, a role which it has retained to the present day.

For me the most relevant question from the point of view of cultural sociology is: what will the future be? Can we stimulate the development of given alternatives in any way? Music can be a tool of violence and oppression, but also a tool of liberation and two-way communication. A lack of awareness of the functions of music makes it possible for the forces of violence to 
operate in the guise of totally innocent "entertainment" or "cultural heritage." Beethoven, for example, may become a weapon used by disreputable political movements based on racist values. The various functions of music are frequently represented by individuals who, instead of looking for a cooperative network, create hierarchic levels: one says that classical music is best and therefore most valuable, another that the therapeutic function of music is more important than anything else, a third that popular music is the most central kind, and a fourth regards folk music or "Swedish music" as our cultural heritage deserving of the first priority, and so on. The cultural sociologist must learn to put the functions of music together, to construct them like a puzzle in order to show that cooperation is the only road to a musical UTOPIA. All the technological prerequisites are there. But the humanistic ones are missing.

What do we have to build on in terms of existing methods in music sociology? I will now present a few examples from among the flora of music sociology.

\section{Methods in Music Sociology in Theory and Practice}

Like so much else in musicology, a general history of the discipline of music sociology remains to be written. Few fields in musicology have stimulated so much discussion, premeditated stabs in the back, and hard knocks over the head. Why has music sociology caused so much upset? Probably for several reasons: music sociology has generally been central to debates on contemporary culture, has sometimes been the basis of political decisions, and its representatives have often been scholars with more or less explicit intentions of changing the future of music with their research. But there are other reasons as well for which music sociology has been unusually effective in raising the adrenaline level of musicologists: it has made the individual give way to the collective, the group, the class, as an object for study. The isolated work has had to step down in favor of the genre. The sociology of music has attempted to break with the tradition in music history that has asserted the individual composer, the individual work, to be central. Yet attempts to explain music and musical phenomena from the point of view of society are nothing new: we can follow this tradition straight up from Plato. Nor has it been the object for such strident arguments in the scholarly tradition. Sociology 
of music is a difficult area. Many people have abandoned the field and some, such as Tibor Kneif (1971) and Vladimir Karbusický (1975), have made "apologias" in the form of more or less well-founded criticism. I understand them. It is easier to vanish into the lap of established musicology, to be able to work with safe, traditional, accepted methods, than to attempt to describe the kaleidoscope of contemporary music in a social context.

The term "sociology of music" came into being in the early decades of the twentieth century. Max Weber's Die rationallen und soziologischen Grundlagen der Musik (1921) is subtitled "Soziologie der Musik,". probably by the publisher, Theodor Kroyer. Under the concept "sociology of music" the most widely disparate phenomena have been assembled, which for one reason or another appear to be "anomalies" in the traditional paradigm of musicology. (Various examples can be found in Kneif [1975].)

Although the sociology of music was formulated in Central Europe (see, e.g., Boettiger [1931]) we must not forget that general theories of music and society were developing simultaneously in the Soviet Union. Boris Asaf'yev's Muzikal'naya forma kak protsess [Musical Form as Process] (1930/47) is one of the results which, at last, has reached researchers in the Western world. In the Soviet Union there is a processual amalgamation of historical materialism as a scientific method, sociology as a scientific field, and education in humanistic thinking. Asaf'yev's turgid and rather heavy theory was undoubtedly an effort to create a "paradigm of music sociology."

The individual who became the pioneer of music sociology in Western Europe was Theodor W. Adorno. In his article "Zur gesellschaftlichen Lage der Musik" (1932) he formulated a model for the study of music in society. He later made this model more detailed in various respects but made no major changes in its basic construction. Asaf'yev and Adorno looked for their explanations in the music itself. On the other hand, the third major contribution to music sociology, the market survey, developed primarily in the United States in the 1920s and 1930s, but became scientifically sophisticated only after World War II.

Thus, in its beginnings, music sociology was an amalgamation of:

1) The general discussion about music in society, particularly characteristic of Germany in the 1920s;

2) scientifically-based music planning founded on his- 
torical materialism, tested in the young Soviet nation in the 1920s and formulated in terms of musicology by Asaf'yev; 3) the musical analysis and research in cultural sociology of Adorno;

4) market surveys, particularly developed in the United States.

There is then a successively built-up connection between various fields within musicology, music history, technology of music, and the like. Music sociology did not begin as an academic discipline: we must find its roots in such things as journalistic debate, cultural-political policy, and market studies. Its entry into the academic arena has not taken place without resistance, especially since its representatives often break with the traditional academic ambition only to describe and analyze without wanting to go on to change reality.

\section{Empirical Sociology of Music}

How is an interest in research into music sociology awakened? Generally more out of a need than out of scientific curiosity: something needs to be explored in order to bring about a change in music. One such example is Musik und Sozialstruktur: Theoretische Rahmenstudie und Forschungspläne, published in West Germany in 1974. The authors were three sociologists: Bernd Buchhofer, Jürgen Friedrichs, and Hartmut Lüdtke. The publisher and initiator was a musicologist, Hans-Peter Reinecke. The aim of the study was to develop a program for a broad research project in music sociology on music in West German society. The program was funded by the Volkswagen foundation. Let us pause for a moment to examine the intentions presented by Reinecke in the introduction to the book. Its first objective is to estimate the scope of music interest today, so that music can at least retain its present status in society. For music is an invaluable means of communications for human life, a form of communication that today is being underestimated, devalued, and deformed. Reinecke is pessimistic in the face of increasing economic stringency in the area of culture, but he concludes with an optimistic prophecy: "If the idea is revolutionary, reality cannot resist" (Buchhofer et al. 1974: 32). ${ }^{1}$ This hope of the victory of the spirit over material is related to a view of music inspired by Adorno and Jürgen Habermas. But note that Reinecke moves away from Adorno's elitist view of music and tries to discover a "democracy of 
music" including the possibility of acknowledging the aesthetic and functional value of many kinds of music. This makes a strange kaleidoscope, but still music is defined as a system, a system of components, moving from elements of individual psychology to broad political and ideological systems. The prerequisite for the system being able to hold up is "value neutrality," that is, setting various musical forms and functions alongside one another. This same "value neutrality" was expressed as early as 1955 in Paul Honigsheim's "Musikformen und Gesellschaftsformen" and in 1957 in Alphons Silbermann's Wovon lebt der Musik? Die Prinzipien der Musiksoziologie. Where does this "value neutrality" originate? What is its scientific-theoretical significance? Its point of departure is sociological. Honigsheim, the sociologist, for example, bases his theses on music and society on sociological theory. Göran Nylöf's definition in his 1967 study of music listening habits in Sweden belongs to the same category:

We will not, however, provide any fixed definition of the phenomenon of music, but rather indicate that the music sociologist must be prepared to accept any phenomenon which any group or minority in society cares to classify under the heading of "music" as an interesting point of departure for studies in music sociology. In accordance with this point of view, the definition of the phenomenon of music is an empirical question which must be answered with empirical research (1967: 7).2

The description of music as a system or the survey of music listening habits of this kind requires either value neutrality-that is, the definition of musical genres by labels-or a sophisticated theory of music philosophy which gives us a basic categorization of values. Adorno attempts, in his research, to give us the latter.

Adorno's "Ideen zur Musiksoziologie" (1959) provides an example of some of his main theses. (They recur in approximately the same form in his Einleitung in die Musiksoziologie [1962].) Adorno attempts to assert the creative functions and autonomy of both research and art. It thus follows that he cannot accept the division of music into production, reproduction, and consumption. It is instead the obligation of the researcher to provide a critical analysis of various constructions of society. For Adorno, the sociology of music is the study of music in an internal $(=$ music $)$ and an external (= society) vessel of communication, where the status and function of music in society 
must always be related to what society considers music to include. Using this model, it is then possible to discuss, for example, how great independent music, which is basically critical of society, can be transformed into a reinforcement of a current ideology. For Adorno there is at best a conflict between the social contents of a work and the society in which it is produced so that the music provides true criticism and functions as an artistic explosive force. Sadly enough music is too often transformed into consumer goods. Adorno warns against the use of sociological concepts that are not based on musical material and he sees a danger in thus sanctioning social interventions in music.

What, then, according to Adorno makes music sociology productive? It is not sufficient to trust in that which is offered by the petrified music conservatories and the scholars of musicology: Adorno presents a vision of music sociology in the future, with intensive methods of music analysis which are able to penetrate more deeply into the "spiritual content" of music. According to Adorno, the function of the sociology of music in society can easily degenerate and it may begin to conceal problems instead of illuminating them. Research in music sociology must bear critical duties, studying, for example, the way in which music is neutralized into a cultural industry and cultural prattle.

An interesting attempt was made by the Czechoslovakian music researcher Vladimir Karbusicky in the 1960s to decode the aesthetic and ideological content of music via interviews. I will try here to summarize some of the ideas in his Empirische Musiksoziologie: Erscheinungsformen, Theorie und Philosophie des Bezugs "Musik-Gesellschaft" (1975).

Karbusicky begins with a study of the concepts and aesthetics of "light" and "serious" music. With the aid of various methodological tools he defines and delimits two different musical levels in industrialized society. The first is more readily accessible "social music," the other more demanding "recital music." This idea as such is not original; one of the historians of music who has previously provided it with a scholarly interpretation is Heinrich Besseler (1959a \& 1959b). But Karbusicky attempts both to make a deeper analysis in which the two levels are related to one another from the point of view of function and characteristics and to relate them to the social structure. He finds the two musical levels to be irreconcilably 
opposed in an industrialized society, and that all attempts to reconcile them are ideological. For example, the popularization of various forms of "recital music" is simply a matter of emphasizing the entertainment element. Karbusický does not deny that there may be value in entertainment music, but he implies that it is the typical "music of the masses" while other forms are "elite music" which can only be enjoyed by certain individuals with certain given, active characteristics. There is no way in which this "recital" or classical music can be spread to the masses. This would only have a negative effect on the music itself. Unfortunately, Karbusickýs work is marked by a deterministic-elitist world view: music will remain unchanged as long as society is the industrial society. The relationship between the masses and the elite is basically considered one between two immobile constants.

Karbusicky's second study concerns the social factors involved in aesthetic experience. He begins this study as well with a number of interesting analyses from the point of view of music sociology. He reports on trials run with music as a testing material and question formulations which provide empirically valuable facts. Karbusický is also well aware that various factors can affect research outcome, and of the nature of the aesthetic experimental situation as a "one-time occurrence" which can never be repeated identically, without the subject's having changed. In one of the experiments Karbusický used a symphonic poem by Bedrich Smetana and a piece of electronic music by Herbert Eimert in order to elucidate the "cultural contact" and musical experiences of the individuals interviewed. Karbusicky had the individuals describe sounds, and these descriptions then formed the basis of various analyses of experience. But in this study as well Karbusicky assumes that his own aesthetic preferences are a general norm on the basis of which the statements made by others may be grouped hierarchically.

Groups with taste in music very different from that of Karbusický are even characterized as "underdeveloped" with regard to some aspects of music. Nevertheless he has hope that his musical values will manage to survive: "Fortunately there is empirical evidence that less educated classes at least have some notion of what is socially-culturally valuable although such values may be inaccessible to them" (1975: 72). ${ }^{3}$ It is from this starting point that Karbusicky goes on to deal with theories including reflection theory. 
In the third study, too, a study of the sociology and anthropology of music listening, Karbusický begins by reporting on a number of interesting experiments in music sociology. Among others, he has performed one study in which he played a piece of music, interrupted it, and then asked the subject: "What comes next?" His primary aim was to study the significance of an individual's readiness to participate actively in his relationship to various kinds of music. In another interesting study, Karbusický presented music to two groups, one of which had cultural contact with the particular type of music, the other of which had none at all. It can be seen from Karbusickýs presentation that individuals project experiences from their environment upon the music to which they listen, irrespective of whether or not the music is a part of their own culture. Karbusický's next step is to attempt to distinguish which aspects are "anthropologically" determined and which "socially" determined.

Here Karbusický also has very clearly defined values regarding music and the experience of music. His experiments in music-semiotics lead to the characterization of two types of music listeners. The one group is comprised of individuals who listen to music as ritual, in a sort of "beat-trance," shrouded in subconscious natural forces. These people listen with no social awareness. The other group is comprised of individuals who, by listening analytically, give indications of critical social awareness. Since in the first chapter Karbusický divided music into two levels which prove to be well-adapted to the two types of listeners, the world vision that finally emerges is one of complete and rigid musical duality.

Karbusický also attempts to elucidate the field of interaction between the individual, the group, and society as it is held together by the components of taste, behavior, and demands. The individual is oppressed by the demands of society, by normative pressure, group pressure, and the socialization process into a system the objective of which is adaptation. All the individual can trust in the face of these destructive, collective forces is his own activity and power.

Can music sociology exist under the shadow of an elitist, idealistic world view? Hardly. Kneif and Karbusický have trod the path from more or less explicit historical materialism to increasingly marked idealism, and as they did so they began increasingly vehemently to deny the existence of a dialectic 
relationship between music-man-society. Karbusický's most strident attack is against reflection theory in its classic, Leninistic formulation. He is well aware of the fundamental importance of this theory to the paradigm of music sociology. As examples of musicological interpretations of reflection theory let us examine both the East German aesthetician and musicologist Günther Mayer's “Zur Dialektik des musikalischen Materials" (1966) and the West German aesthetician and musicologist Albrecht Riethmüller's Die Musik als Abbild der Realität zur dialektischen Widerspiegelungstheorie in der Ästhetik (1976).

Mayer's points of departure are the techniques for the analysis of music and society of Hanns Eisler and Adorno. With the aid of a semiotic vision he penetrates the musical material and its relation to disparate musical functions. According to Mayer, it is possible to deepen the study of the sociology of music by examining conflicts in musical material. Musical material is seen as a kind of productive force which cannot at all be explained as mechanically contingent upon society. For example, a progressive attitude toward music is not at all necessarily related to a socially or politically progressive attitude.

In Mayer's opinion, music can change society, make us aware of the world around us, and, by changing the way in which we experience the world, give us new awareness. However, this type of music requires that the composer be politically aware, according to Marxist aesthetics, so that music is, without compulsion, placed at the service of progressive social development.

Riethmüller, on the other hand, is of the opinion that the reflection theory of music takes all too little into consideration the mathematical principles of order and form related to music. He asserts that these can be raised to principles for the reproductive nature of music, and proposes a fusion of the reflection theory and methods of structural analysis. With the aid of hermaneutics and content analysis it would be possible, according to Riethmüller, to further develop reflection theory, but only if traditional music analysis is broadened to include not only the work but also its effects. Riethmüller also discusses a difference in the way music is evaluated by the proponents and opponents of reflection theory; the latter do not generally acknowledge the social-pedagogical and educative 
significance and nature of music. Riethmüller sees the importance of Marxist scientific analysis as lying in the very tension between the sensual pleasure and utilitarian value of music.

Riethmüller also discusses the limitation of reflection theory; it cannot, for example, be applied to avant-garde music and is therefore primarily useful in terms of entertainment music and the like. This is related to the opinion Riethmüller has derived from Adorno regarding tonality as a second nature: tonality is to music as the presentation of objects is to art. When it is abandoned, the "mirror" is blind to reflection.

Riethmüller is certainly right in asserting that at present the most successful object for analyses using the "reflex" of reflection theory is entertainment music. This is especially so because of the large amount of material available about its effects and its relation to the economic and social basis of society (see, e.g., Tagg 1979).

\section{Three Thoughts on Music Sociology}

At the Department of Musicology of the University of Gothenburg we have carried out empirical studies in the sociology of music with varying results. Our point of departure has basically been the methods and theories cited above. I would summarize our conclusions in the following three paragraphs:

1) Without deep musical analysis, a fundamental understanding of the material and functions of music, the sociology of music can easily degenerate into a sort of journalistic expression of opinions. Sociologists may only be allowed to work with labels and generalized genre classifications if musicology can provide these labels with a detailed scientific description, moving from the microlevel of the isolated work to the macrolevel of the genre. The conflict between the individual, isolated work and the genre must be dissolved in future music sociology.

2) The most difficult of all research is commissioned research. It must be carried out by post-graduate-level researchers with a great deal of experience and the ability to develop methods and theories on the basis of a thorough knowledge of musicology. A young, relatively inexperienced musicologist faces altogether too many new problems in this situation. He also lacks the "research status" often 
required by the representatives of society. This type of research should be carried out by a team that includes the music sociologist, trained in musicology, alongside the cultural sociologist, trained in sociology, the commissioning party, and the "subject" of the study. The research should be made public during the study period. Publicity in the mass media may thus stimulate public interest and discussion. Reports should be made in the form of exhibitions, articles in popular magazines, and the like in order to establish a wide dispersion of information.

3) The work of the music sociologist must include the discovery of explanatory models for contemporary musical life via research in music history. This will bring many of the traditional techniques and methods of musicology to the fore and mean that the musicologist need not have a special "sociological" profile in order to be included in the research team, although he must of course be able to conduct scientific discussions with the other members of the study group.

\section{Conclusion}

What are the possibilities, with our current awareness of music history and our fragments of theory in music sociology, of working for the kind of objective formulated on the first page of this paper? As an academic wallflower, musicology has very little hope. But as an integrated part of interdisciplinary and intercultural research I believe that it can be an extremely important voice in the mixed chorus of cultural sociology which includes sociologists, anthropologists, and historians.*

*For a detailed review of the sociology of music see Blaukopf (1982). 


\section{NOTES}

1. "Ist die Vorstellung erst revolutioniert, dann hält die Realität nicht mehr stand."

2. "Vi kommer dock inte att här ange någon fixerad definition på fenomenet utan i stället påtala att man som musiksociolog får vara beredd att acceptera varje fenomen, som någon grupp eller minoritet $\mathrm{i}$ samhället vill beteckna med termen 'musik' som en intressant utgångspunkt för musiksociologiska studier. Enligt detta synsätt blir definitionen av fenomenet musik en empirisk fråga, som måste besvaras med empirisk forskning."

3. "Zum Glück zeigt die Empirie, dass die einfachen Schichten eine Vorstellung von den gesamtgesellschaftlichen nützlichen, kulturellbedeutsamen Werten haben, wenn auch diese ihnen nicht zugänglich sind."

\section{REFERENCES}

ADORNO, T.W.

1932: "Zur gesellschaftlichen Lage der Musik," Zeitschrift für Sozialforschung, I/1-2, 103-24: I/3, 356-78.

1959: "Ideen zur Musiksoziologie," in Gesammelte Schriften, Vol. 16: Musikalische Schriften I-III. Frankfort: Suhrkamp, 9-23.

1962: Einleitung in die Musiksoziologie. Frankfort: Suhrkamp. ASAF'YEV, B.V.

1930/ Muzikal'naya forma kak protsess [Musical Form as

47: Process]. Moscow: Muzyka; 2nd ed., 1971: German trans., Leipzig, 1976.

BESSELER, $\mathrm{H}$.

1959a: Das musikalische Hören der Neuzeit. Berlin: Akademie Verlag.

1959b: "Umgangsmusik und Darbietungsmusik im 16. Jahrunderts," Archiv für Musikwissenschaft, XVI/1-2, 21-43.

BLAUKOPF, K.

1982: Musik im Wandel der Gesellschaft. Munich: R. Piper \& Co. Verlag.

BOETTIGER, $\mathrm{H}$.

1931: "Musiksoziologie," Melos: Zeitschrift für neue Musik, No. 10, 188-91. 
BUCHHOFER, B., FRIEDRICHS, J., and LÜDTKE, H.

1974: Musik und Sozialstruktur: Theoretische Rahmen studie und Forschungspläne. Mit einer Vorbemerkung von HONIGSHEIM, P. Hans-Peter Reinecke. Cologne: Arno Volk-Verlag.

1955: "Musikformen und Gessellschaftsformen," in Bernsdorf, W. and Eiserman, G., eds., Die Einheit der Sozialwissenschaften: Franz Eulenberg zum Gedächtnis. Stuttgart: Enke, 214-25.

KARBUSICKÝ, V.

1975: Empirische Musiksoziologie: Erscheinungsformen, Theorie und Philosophie des Bezugs "Musik-Gesellschaft." Wiesbaden: Breitkopf und Härtel.

KNEIF, T.

1971: Musiksoziologie. Cologne: Musikverlag Hans Gerig. KNEIF, T., ed.

1975: Texte zur Musiksoziologie. Cologne: Arno Volk-Verlag. MAYER, G.

1966: "Zur Dialektik des musikalischen Materials," Deutsche Zeitschrift für Philosophie, XIV 1367-88.

NYLÖF, G.

1967: "Musikvanor i Sverige," supplement to Statens offentliga RIETMÜLLER, A. utredningar 1967: 9, 5-270. Stockholm: Esselte AB.

1976: Die Musik als Abbild der Realität zur dialektischen Widerspiegelungstheorie in der Ästhetik. Wiesbaden: Franz Steiner Verlag GMBH.

SILBERMANN, A.

1957: Wovon lebt die Musik? Die Prinzipien der Musiksoziologie. Regensburg: Gustav Bosse Verlag.

TAGG, P.

1979: Kojak-50 Seconds of Television Music: Toward the Analysis of Affect in Popular Music. Gothenburg: University of Gothenburg, Studies from the Department of Musicology, No. 2.

WEBER, M.

1921: Die rationallen und soziologischen Grundlagen der Musik. Munich: Drei Masken Verlag. 